\title{
Neosartorya glabra polygalacturonase produced from fruit peels as inducers has the potential for application in passion fruit and apple juices
}

\author{
Poligalacturonase de Neosartorya glabra produzida a partir de cascas de frutas como \\ indutores tem potencial para aplicação em sucos de maracujá e maçã
}

\begin{abstract}
Vanessa Elisa Pinheiro',2, Carla Cristina Villela Desagiacomo ${ }^{2}$, Michele Michelin ${ }^{1}$, Alexandre Maller ${ }^{2}$, Lummy Maria Oliveira Monteiro ${ }^{2}$, João Atílio Jorge ${ }^{1}$, Maria de Lourdes Teixeira de Moraes Polizeli ${ }^{1,2 \star}$
\end{abstract}

${ }^{1}$ Universidade de São Paulo (USP), Faculdade de Filosofia, Ciências e Letras de Ribeirão Preto, Departamento de Biologia, Ribeirão Preto/SP - Brazil ¿Universidade de São Paulo (USP), Faculdade de Medicina de Ribeirão Preto, Departamento de Bioquímica e Imunologia, Ribeirão Preto/SP - Brazil

\section{*Corresponding author:}

Maria de Lourdes Teixeira de Moraes Polizeli, Universidade de São Paulo (USP), Faculdade de Filosofia, Ciências e Letras de Ribeirão Preto, Departamento de Biologia, Av. Bandeirantes, 3900, CEP: 14040-901, Ribeirão Preto/SP - Brazil, e-mail: polizeli@ffclrp.usp.br

Cite as: Neosartorya glabra polygalacturonase produced from fruit peels as inducers has the potential for application in passion fruit and apple juices. Braz. J. Food Technol., v. 20, e2016163, 2017.

\section{Summary}

Polygalacturonases are enzymes with the biotechnological potential for use in fruit juice clarification and for the enhancement of filtration efficiency. The aim of this work was to assess the production of polygalacturonase by the fungus Neosartorya glabra by means of solid-state and submerged fermentation using fruit peel residues as the carbon source, and also apply the enzyme in the clarification and decrease in viscosity of passion fruit and apple juices. The highest polygalacturonase $(4.52 \mathrm{U} / \mathrm{g} / \mathrm{h})$ production was obtained by means of submerged fermentation in Vogel's medium (1964) containing orange peel - Bahia variety (Citrus sinensis), at a concentration of $1.5 \%$ (w/v, dried mass) at $30-35^{\circ} \mathrm{C}$ for $72 \mathrm{~h}$. The polygalacturonase of the crude extract presented optimal activity at $60^{\circ} \mathrm{C}$ and $\mathrm{pH} 5.5$. The enzyme retained around $90 \%$ of the initial activity after 180 minutes at $40^{\circ} \mathrm{C}$, and $50 \%$ of the initial activity after 150 minutes at $50^{\circ} \mathrm{C}$. The enzyme was shown to be stable at acid $\mathrm{pH}$ values (3.0-6.5) after 120 minutes at $25^{\circ} \mathrm{C}$. All these favourable enzymatic properties make the polygalacturonase attractive for potential uses in the industry of pectin-rich fruit juices, since the application of the crude extract to passion fruit (Passiflora edulis) juice caused an $80 \%$ reduction in viscosity and $75 \%$ decrease in light absorbance. In the processing of apple pulp juice (Malus domestica), there was a 50\% reduction in viscosity and $78 \%$ decrease in light absorbance.

Keywords: Neosartorya glabra; pectin; polygalacturonase; peel; viscosity.

\section{Resumo}

Poligalacturonases são enzimas com potencial biotecnológico para aplicação na clarificação de sucos de frutas e para aumento da eficiência da filtragem. O objetivo deste trabalho foi avaliar a produção de poligalacturonase pelo fungo Neosartorya glabra, por fermentação submersa e em estado sólido, usando resíduos de casca de frutas como fonte de carbono, além de avaliar também a aplicação desta enzima na clarificação e na diminuição de viscosidade de sucos de maracujá e maçã. A maior produção de poligalacturonase $(4,52 \mathrm{U} / \mathrm{g} / \mathrm{h})$ foi obtida por fermentação submersa em meio de Vogel (1964) contendo cascas de laranja (Citrus sinensis), variedade Bahia, na concentração 1,5\% (m/v, massa seca), a $30-35^{\circ} \mathrm{C}$ por $72 \mathrm{~h}$. A poligalacturonase do extrato bruto apresentou atividade ótima a $50-60^{\circ} \mathrm{C}$ e pH 5,5 . A enzima reteve cerca de $90 \%$ da atividade inicial após 180 minutos, a $40^{\circ} \mathrm{C}$, e $50 \%$ da atividade inicial após 150 minutos, a $50^{\circ} \mathrm{C}$. A enzima mostrou-se estável em pH ácido $\left(3,0\right.$ a 6,5) após 120 minutos, a $25^{\circ} \mathrm{C}$. Todas estas propriedades enzimáticas fazem desta poligalacturonase uma alternativa atrativa para a aplicação na indústria de sucos de frutas ricas em pectina, uma vez que a aplicação do extrato enzimático bruto no processamento de suco de polpa de maracujá (Passiflora edulis) causou uma redução da viscosidade de $80 \%$ e uma diminuição da absorbância da luz de $75 \%$. No processamento de suco de polpa de maçã (Malus domestica), houve uma redução da viscosidade de 50\% e uma diminuição da absorbância da luz de $78 \%$.

Palavras-chave: Neosartorya glabra; pectina; poligalacturonase; casca; viscosidade. 
Pinheiro, V. E. et al.

\section{Introduction}

Pectinases are enzymes with important industrial applications (IRSHAD et al., 2014), representing approximately $25 \%$ of the commercial enzyme production (MAKKY; YUSOFF, 2015). These enzymes can be divided into protopectinase, de-esterifying and depolymerizing pectinases according to their mode of attack of the pectin backbone. Polygalacturonases $(\mathrm{PG})$ are the depolymerizing pectinase most used in industries and also the most studied (NEVADITA et al., 2013). PG hydrolyses the $\alpha-1,4$-glycosidic linkages between the galacturonic acid residues in pectin, an acidic polysaccharide complex that occurs mainly in the middle lamella of higher plants (RIDLEY et al., 2001; ZENI et al., 2011; TU et al., 2013).

Pectinases are secreted in high amounts by some fungal species and are used in biotechnological applications, for example, in the liquefaction and extraction of plant tissues, the degumming of natural fibres, the reduction of viscosity, increase in yield and clarification of fruit juices (UENOJO; PASTORE, 2007). In addition, the study of fruit peels as a cheap carbon source for pectinase production is a growing segment in the biotechnological industry (BATOOL et al., 2013).

There are a great variety of fruit juices on the market, such as apple and passion fruit juices, which are commonly consumed and well-established products.

The culture of passion fruit has grown over the last 30 years on the tropical fruit market, on account of the fast economic return and distribution throughout the year (MELETTI, 2011). The most cultivated species in the world is the yellow passion fruit species (Passiflora edulis f. flavicarpa). Brazil is the world's largest producer and consumer of this fruit, accounting for $50-60 \%$ of the total world production (OLIVEIRA et al., 2016). In 2013, the world apple production was approximately 80 million tons according to FAOSTAT (2016), and the productivity of the apple in Brazil is around 15-30 tons/ha (SEBRAE, 2016). Apples and passion fruits are rich sources of pectin. Apple pulp contains from 0.6 to $1.5 \%$ pectin while passion fruit pulp contains $0.5 \%$ pectin (CANTERI, 2011). Thus the application of polygalacturonases to viscous and jellied fruit juices is an alternative to make them more transparent and homogeneous (SIN et al., 2006; ONGARATTO; VIOTTO, 2016), since these enzymes can break down the pectin present in the cell wall, resulting in a reduction in the solids content, facilitating filtration and increasing the overall juice production. The aim of this work was to describe the production of PG by Neosartorya glabra with fruit peel as the carbon source, and analyse the effect of crude PG on the apple and passion fruit juices from the viscosity and light absorbance.

\section{Material and methods}

\subsection{Microorganism}

Neosartorya glabra was isolated from the State Forest of Bebedouro in Bebedouro city, São Paulo State, Brazil. This is a conservation area, managed by the Instituto Florestal do Estado de São Paulo (IFESP), and the forest has 99.41 hectares, an altitude of 570 meters, warm weather $\left(17.2-22.7^{\circ} \mathrm{C}\right)$ and a vegetation consisting of pines and eucalyptus (IF, 2016).

Neosartorya glabra was identified and preserved by the URM Culture Collection at the Federal University of Pernambuco (Brazil). Stock cultures are being preserved under the register number of 7294 and the fungus was maintained in the laboratory on PDA medium slants (Himedia) at $4^{\circ} \mathrm{C}$.

\subsection{PG production}

PG production was evaluated in solid-state fermentation (SSF) and submerged fermentation (SbmF). SbmF was carried out by inoculating $1 \mathrm{~mL}$ of spore solution ( $8 \times 10^{7}$ spores) into $125 \mathrm{~mL}$ Erlenmeyer flasks previously sterilized at $127^{\circ} \mathrm{C}$ and $1.5 \mathrm{~atm}$ for 15 minutes, containing $25 \mathrm{~mL}$ of Vogel's minimal medium (VOGEL, 1964). For the preparation of the Vogel minimum culture medium, the stock solution was diluted 50 -fold with distilled water, and a $0.01 \%$ biotin solution and $1 \%$ carbon source added as described below. The stock solution contained $125 \mathrm{~g} \mathrm{Na}_{3}$ citrate. $2 \mathrm{H}_{2} \mathrm{O} ; 250 \mathrm{~g}$ anhydrous $\mathrm{KH}_{2} \mathrm{PO}_{4} ; 100 \mathrm{~g}$ anhydrous $\mathrm{NH}_{4} \mathrm{NO}_{3} ; 10 \mathrm{~g} \mathrm{MgSO}{ }_{4} .7 \mathrm{H}_{2} 0 ; 5 \mathrm{~g}$ $\mathrm{CaCl}_{2}$. $2 \mathrm{H}_{2} \mathrm{O} ; 5 \mathrm{~mL}$ trace element solution; and diluted to $1 \mathrm{~L}$ with distilled water. An aliquot of $2 \mathrm{~mL}$ chloroform was added as a preservative. The stock solution was stored at room temperature. The solution of trace elements was composed of $5 \mathrm{~g}$ citric acid. $1 \mathrm{H}_{2} \mathrm{O} ; 5 \mathrm{~g} \mathrm{ZnSO}{ }_{4} 7 \mathrm{H}_{2} \mathrm{O} ; 1 \mathrm{~g}$ $\mathrm{Fe}\left(\mathrm{NH}_{4}\right)_{2}\left(\mathrm{SO}_{4}\right)_{2} \cdot 6 \mathrm{H}_{2} \mathrm{O} ; 0.25 \mathrm{~g} \mathrm{CuSO}_{4} \cdot 5 \mathrm{H}_{2} \mathrm{O} ; 0.05 \mathrm{~g} \mathrm{MnSO}_{4}$ $\mathrm{H}_{2} \mathrm{O} ; 0.05 \mathrm{~g}$ anhydrous $\mathrm{H}_{3} \mathrm{BO}_{3} ; 0.05 \mathrm{~g} \mathrm{Na}_{2} \mathrm{MoO}_{4} 2 \mathrm{H}_{2} \mathrm{O}$, and $100 \mathrm{~mL}$ distilled water. The media were supplemented with carbon sources: $1 \%$ (w/v) of fruit peel (residues), such as apple (Malus domestica var. Fuji), passion fruit (Passiflora edulis var. Yellow), banana (Musa genus var. Silver), pear (Pyrus communis var. Williams), guava (Psidium guajava var. Red), orange (Citrus sinensis var. Bahia, Lima, Pear and Rubi); lemon (Citrus aurantifolia var. Tahiti, Crave and Sicilian) and tangerine (Citrus reticulate) peels.

The production of PG in SbmF was also evaluated from mixtures of tangerine and orange peels (Pear and Bahia varieties); and from mixtures of lemon peels (Tahiti and Sicilian varieties). All fruit peels used in SbmF were obtained after drying at $50^{\circ} \mathrm{C}$ for $12 \mathrm{~h}$ and grinding into fine particles $(1 \mathrm{~mm})$. The cultures were incubated at $30^{\circ} \mathrm{C}$ (static condition) for $96 \mathrm{~h}$, vacuum filtered using a Büchner funnel and Whatman $n^{\circ} 1$ filter paper, and the cell-free filtrates obtained used to determine the extracellular PG activity. SSF was carried out by inoculating $1 \mathrm{~mL}$ of 
Neosartorya glabra polygalacturonase produced from fruit peels as inducers has the potential for application in passion fruit and apple juices

Pinheiro, V. E. et al.

spore solution ( $6.8 \times 10^{7}$ spores) into $125 \mathrm{~mL}$ Erlenmeyer flasks previously sterilized at $127^{\circ} \mathrm{C}$ and $1.5 \mathrm{~atm}$ for 15 minutes, containing $2 \mathrm{~g}$ of dried fruit peels (apple, passion fruit, banana, pear, guava, orange (var. Bahia) and lemon (var. Tahiti) as the carbon source and $3 \mathrm{~mL}$ of distilled water. The flasks were incubated at $30^{\circ} \mathrm{C}$ in an incubator (static conditions) with $70 \%$ of humidity for $96 \mathrm{~h}$. The fruit peels used in SSF were obtained by drying at $50^{\circ} \mathrm{C}$ and retaining on a $0.5 \mathrm{~mm}$ screen. After cultivation, the culture media were suspended in $30 \mathrm{~mL}$ of distilled water with agitation (100 rpm) for $30 \mathrm{~min}$ at $4^{\circ} \mathrm{C}$. Subsequently, the cultures were vacuum-filtered using a Büchner funnel and Whatman $n^{\circ} 1$ filter paper. The cell-free filtrates obtained were used to determine the extracellular PG activity.

\subsection{Effect of cultivation temperature and time on PG production}

The experiment to determine the effect of cultivation temperature was carried out using SbmF after inoculating the fungus into Vogel's medium containing orange peel (var. Bahia) as the carbon source (1\%). The cultures were incubated (static conditions) at $25,30,35$ and $40^{\circ} \mathrm{C}$ for $96 \mathrm{~h}$ and the PG activity then determined.

The time-course of $P G$ production was also carried out in Vogel's medium (using orange peel from the Bahia variety as the carbon source). The cultures were incubated under static conditions at $35^{\circ} \mathrm{C}$ for 7 days. Samples were withdrawn every $24 \mathrm{~h}$, vacuum-filtered, and the extracellular PG activity determined. The mycelium obtained after filtration was triturated with glass beads in a porcelain mortar and suspended in $30 \mathrm{~mL}$ of $100 \mathrm{mM}$ sodium acetate buffer, $\mathrm{pH}$ 5.0. It was then centrifuged at $13,000 \times g$ for $15 \mathrm{~min}$ at $4^{\circ} \mathrm{C}$ to remove cell debris. The supernatant obtained was used to determine intracellular PG activity.

\subsection{Effect of the carbon source concentration on PG production}

The experiment was carried out using SbmF by inoculating the fungus into Vogel's medium containing orange peel (var. Bahia) as the carbon source. The culture media were supplemented with different concentrations $(0.25-4.0 \%(w / v))$ of dried orange peel and incubated under static conditions at $35^{\circ} \mathrm{C}$ for $72 \mathrm{~h}$.

\subsection{Extraction and quantification of pectin in the fruit peels}

The pectin contents of the apple, passion fruit, banana, guava, orange and lemon peels were analysed according to Carvalho et al. (2006) with modifications. One gram of dry and crushed peels was boiled with $200 \mathrm{~mL}$ of distilled water for one hour. The material was filtered and the volume completed to $500 \mathrm{~mL}$. An aliquot of $100 \mathrm{~mL}$ was withdrawn, and $300 \mathrm{~mL}$ of distilled water and $10 \mathrm{~mL}$ of $1 \mathrm{M}$ sodium hydroxide added with continuous stirring, after which it was held overnight without stirring. A volume of $50 \mathrm{~mL}$ of $1 \mathrm{M}$ acetic acid was then added, and after 5 minutes, $50 \mathrm{~mL}$ of $2 \mathrm{M}$ calcium chloride was added. The solution was boiled for 1 minute, maintained without stirring for 90 minutes and then filtered through Whatman filter paper (3-micron porosity) and dried.

The $\%$ pectin was estimated as follows in Equation 1:

$\frac{\left(\begin{array}{l}\text { Filter paper with the pectin }- \\ \text { previously weighed filter paper }\end{array}\right) \times 100 \times 5(\text { dilution })}{\text { Sample weight }}$

\subsection{PG activity}

The PG activities were determined by the method of Miller (1959), using 3,5 dinitrosalicylic acid (DNS). The assay was carried out with $50 \mu \mathrm{L}$ of the enzyme and $50 \mu \mathrm{L}$ of $1 \%(\mathrm{w} / \mathrm{v})$ substrate: sodium polypectate from Sigma-Aldrich in $100 \mathrm{mM}$ sodium acetate buffer, pH 5.0. The samples were incubated at $60^{\circ} \mathrm{C}$ for $10 \mathrm{~min}$ and $100 \mu \mathrm{L}$ of DNS then added to the assay. The absorbance was measured at $540 \mathrm{~nm}$. The results were obtained using a curve of monogalacturonic acid $(0-1 \mathrm{mg} / \mathrm{mL})$ as the standard. One unit of enzymatic activity was defined as the amount of enzyme that releases $1 \mu \mathrm{mol}$ of reducing sugar per minute under the assay conditions.

\subsection{Effect of temperature on PG activity}

The effect of temperature on PG activity was analysed using the extracellular crude extract from $N$. glabra cultivated on orange peel (var. Bahia). The assays were carried out with the enzyme and $1 \%(\mathrm{w} / \mathrm{v})$ substrate, and incubation at the temperatures of 30 to $70^{\circ} \mathrm{C}$ with $10^{\circ} \mathrm{C}$ intervals.

Thermal stability was determined by a prior incubation of the enzyme at 40,50 and $60^{\circ} \mathrm{C}$ for up to $24 \mathrm{~h}$, at pH 5.5. Samples were withdrawn after 10, 20, 40, 60, 120, 150, 180 min and $24 \mathrm{~h}$ of incubation, and the residual activities measured as described above.

\subsection{Effect of pH on PG activity}

The effect of $\mathrm{pH}$ on the PG activity was also analysed using the extracellular crude extracts from $N$. glabra cultivated on orange peel (var. Bahia). The assays were carried out using the enzyme and 1\% (w/v) substrate, with incubation in $100 \mathrm{mM}$ sodium acetate buffer, from $\mathrm{pH} 4.0$ to 8.5 , with $0.5 \mathrm{pH}$ unit intervals. The pH stability was determined by incubating the enzyme in $100 \mathrm{mM}$ Mcllvaine buffer (citrate-phosphate) (1:1v/v) from pH 3.0 to 7.5 for 120 minutes at $25^{\circ} \mathrm{C}$. After incubation, the residual activities were measured as described above. The control was that of time 0 (zero), when the residual activity was considered to be $100 \%$. 
Neosartorya glabra polygalacturonase produced from fruit peels as inducers has the potential for application in passion fruit and apple juices

Pinheiro, V. E. et al.

\subsection{The effect of enzyme application on fruit juice processing}

The extracellular crude extract obtained from the cultivation of $N$. glabra was used as the source of PG. Apple (var. Fuji) and passion fruit (var. Yellow) pulps were used to analyse the action of PG on the fruit juices. The methodology of application was an optimized version of that reported by Kashyap et al. (2001). The selected fruits were washed, cut and triturated. The sliced apples were maintained in contact with oxygen for $15 \mathrm{~min}$ to avoid the inhibition of pectinase by polyphenols. Twenty grams of sliced and triturated fruits were placed into 125-mL Erlenmeyer flasks and $4.5 \mathrm{U}$ of crude enzyme per gram of fruit added. The control (untreated pulp) was prepared under the same conditions, but using a boiled enzyme extract. The flasks were incubated at $37^{\circ} \mathrm{C}$ for $5 \mathrm{~h}$ with agitation. The fruit juices were then extracted by filtration and the viscosity and turbidity of the extracts studied. The viscosity was analysed using an Ostwald's viscometer. The percentage of decrease in viscosity (A) was calculated according to Roboz et al. (1952), through the Equation 2:

$\mathrm{A}=\left(\mathrm{V}_{0}-\mathrm{Vt}_{\mathrm{t}} / \mathrm{Vo}-\mathrm{Vs}\right) \times 100$

Vo is the flow time (seconds) of fruit pulp treated with inactivated enzyme (control);

$V t$ is the flow time (seconds) of fruit pulp treated with active enzyme;

$V s$ is the flow time (seconds) of the inactivated enzyme plus water

The difference in turbidity between the treated and untreated fruit juice samples was analysed from the light absorbance in a spectrophotometer at different wavelengths (250-570 nm, with $10 \mathrm{~nm}$ intervals) using a glass cuvette.
The untreated sample (control) was the fruit pulp treated with inactivated enzyme.

\section{Results and discussion}

\subsection{The effect of the carbon sources on PG production}

The effect of the fruit peels as PG inducers was analysed using SbmF (Figure 1A) and SSF (Figure 1B). Glucose was used as the control (repression conditions). Using SbmF (Figure 1A) orange peel was the best PG inducer $(4.3 \mathrm{U} / \mathrm{mL})$, followed by lemon peel, which had a production corresponding to $92 \%$ of the activity observed with orange peel. The worst PG inducer was banana peel under the conditions analysed. Using SSF (Figure 1B), guava peel was the best $P G$ inducer $(1.2 \mathrm{U} / \mathrm{mL})$, with a $P G$ production $16.5 \%$ greater than the second-best residue, apple peel.

Table 1 expresses the enzyme productivity (U/gram of dried peel per hour of fermentation) using SbmF and SSF. SbmF showed better enzyme productivity and has the advantages of easy recovery of the extracellular enzymes,

Table 1. Comparison between SbmF and SSF in the production of PG using different carbon sources.

\begin{tabular}{lcc} 
Carbon Source (peel) & $\begin{array}{c}\text { SbmF } \\
\text { (U/g per hour) }\end{array}$ & $\begin{array}{c}\text { SSF } \\
\text { (U/g per hour) }\end{array}$ \\
\hline Glucose (control) & 0.21 & - \\
Banana & 0.44 & 0.03 \\
Guava & 1.29 & 0.18 \\
Orange (Bahia) & 4.52 & 0.06 \\
Lemon (Tahiti) & 4.25 & 0.11 \\
Apple & 2.10 & 0.15 \\
Passion Fruit & 2.89 & 0.07 \\
Pear & 2.70 & 0.09 \\
\hline
\end{tabular}
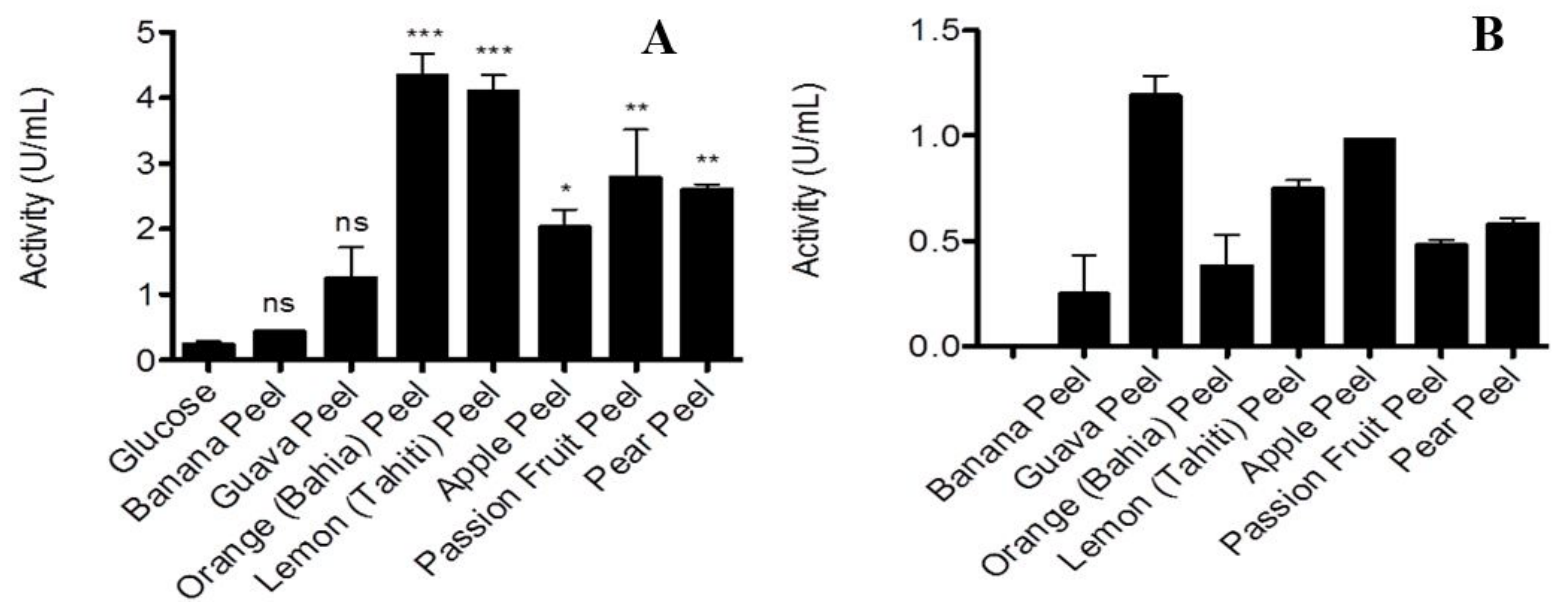

Figure 1. The effect of the carbon sources on PG production. (A) shows the PG activities using SbmF and (B) using SSF. The microorganism was cultivated in Vogel's medium and incubated under static conditions at $30^{\circ} \mathrm{C}$ for $96 \mathrm{~h}$. Symbols: $\left(^{*}\right) \mathrm{p}<0.05$, $\left.{ }^{(* *}\right) p<0.01$ and $\left(^{* * *}\right) p<0.001$ versus Glucose according to the Student Newman Kwels test (SNK); ns - not significant. 
Neosartorya glabra polygalacturonase produced from fruit peels as inducers has the potential for application in passion fruit and apple juices

Pinheiro, V. E. et al.

mycelia and spores. SbmF is a process of a homogeneous nature with easy control of the parameters, such as temperature and agitation (FERNANDÉZ, 2009), and more than $75 \%$ of industrial enzymes are produced using SbmF (SUBRAMANIYAN; VIMALA, 2012). Camargo et al. (2005) reported the production of $3.6 \mathrm{U} / \mathrm{mL}$ of $P G$ by Aspergillus sp. in a medium supplemented with orange (pulp, peel and seeds) as the carbon source. Maller et al. (2011) and Mrudula and Anitharaj (2011) observed that orange peel was the best inducer of pectinase production by $A$. niveus and PG by $A$. niger, respectively.

\subsection{Effect of different varieties of orange and lemon peels on $\mathrm{PG}$ production}

Since orange (Bahia variety) and lemon (Tahiti variety) peels were the sources that stood out as inducers of $P G$ production using SbmF, a study using tangerine and other varieties of orange and lemon peels was carried out (Figure 2). Orange peel (Bahia variety) remained as the best residue for PG production by the fungus $N$. glabra, but orange (var. Pear), tangerine and lemon (var. Tahiti) peels were also shown to be good inducers, presenting $96 \%, 86 \%$ and $90 \%$ of the production observed with the Bahia orange peel, respectively.

Tables 2 and 3 illustrate the influence of mixtures of peels of different oranges and the peels of distinct lemons on PG production from N. glabra, respectively. It can be seen that Bahia orange peel remained as the best inducer of $P G$ production even when using mixtures of other orange peels and tangerine (Table 2), whereas lemon peel (var. Tahiti) was the best PG inducer when compared to the mixtures with lemon peel (var. Sicilian) (Table 3).

Analysing Tables 2 and 3 and Figures 1 and 2, it can be seen that orange peel (var. Bahia) was the best $P G$ inducer. Quantitative analyses for the determination of pectin in the dry peels used in this work showed that banana, guava, apple, lemon, passion fruit and orange peels have $19 \%, 20 \%, 15.5 \%, 15 \%, 16 \%$ and $17 \%$ of pectin, respectively. The values are close and probably other parameters influenced the PG synthesis, such as: the availability of inducers, structural differences of the pectin contents - branching degree, phenol groups, polygalacturonase-inhibiting protein, and the presence of fungicides, pesticides, ions, detergents, urea, 2-mercaptoethanol, vitamins, phosphorus and others (KAUR et al., 2004; TAl et al., 2013; KANT et al., 2013; SCHWAN-ESTRADA et al., 2000). According to Al-Saadi et al. (2009), orange peels contain alkaloids, saponins, terpenes, resins, flavonoids, tannins, phenols and sugars. The orange peels contain $23.8 \%$ of sugar, $4 \%$

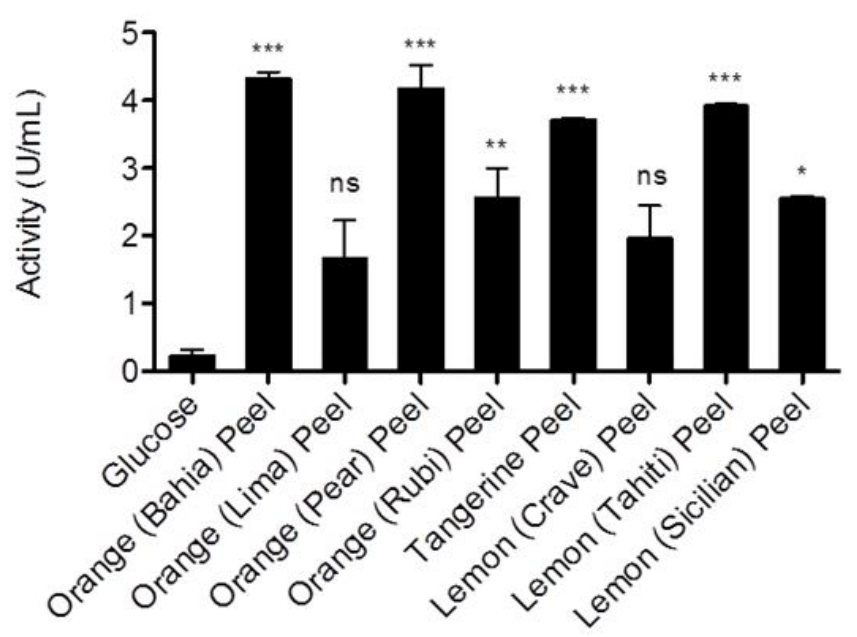

Figure 2. Effect of tangerine peel and different varieties of orange and lemon peels as carbon sources for PG production using SbmF. The microorganism was cultivated in Vogel's medium in a bacteriological incubator at $30^{\circ} \mathrm{C}$ for $96 \mathrm{~h}$. Symbols: $\left({ }^{*}\right) \mathrm{p}<0.05$, $\left.{ }^{(* *}\right) p<0.01$ and $\left(^{* * *}\right) p<0.001$ versus Glucose according to the Student Newman Kwels test (SNK); ns - not significant.

Table 2. Influence of the mixture of some varieties of orange peel on PG production.

\begin{tabular}{ccccc} 
Mixture & Bahia Orange Peel (\%) & Pear Orange Peel (\%) & Tangerine Peel (\%) & Enzymatic Activity (U/mL) \\
1 & 1.00 & - & - & $4.21 \pm 0.32$ \\
2 & - & 1.00 & - & $4.08 \pm 0.4$ \\
3 & - & - & 1.00 & $3.48 \pm 0.2$ \\
4 & 0.50 & 0.50 & - & $2.77 \pm 0.29$ \\
5 & 0.50 & - & 0.50 & $2.25 \pm 0.18$ \\
6 & - & 0.50 & 0.50 & $1.91 \pm 0.01$ \\
7 & 0.75 & 0.25 & - & $2.67 \pm 0.03$ \\
8 & 0.25 & 0.75 & - & $2.81 \pm 0.28$ \\
9 & 0.75 & - & 0.25 & $2.32 \pm 0.13$ \\
10 & 0.25 & - & 0.75 & $2.48 \pm 0.46$ \\
11 & - & 0.75 & 0.25 & $2.85 \pm 0.45$ \\
13 & - & 0.25 & 0.75 & $2.45 \pm 0.28$ \\
\hline
\end{tabular}

The microorganism was cultivated in Vogel's medium and incubated under static conditions at $30^{\circ} \mathrm{C}$ for $96 \mathrm{~h}$. 
Neosartorya glabra polygalacturonase produced from fruit peels as inducers has the potential for application in passion fruit and apple juices

Pinheiro, V. E. et al.

of protein, $11.86 \%$ of water and $5.34 \%$ of ash. In addition, according to Canteri et al. (2012), orange peel has a high pectin content (3.5-5.5\% of pectin per fresh-fruit weight), which is a good inducer of PG production. Furthermore, this result is very interesting, since orange juice is one of the most widely consumed beverages nowadays and consequently the amount of waste (mostly peel) generated is large.

The cultivation of orange has become an important economic sector in the United States (Florida and California), Brazil, Mexico, Pakistan, China, India, Iran and the Mediterranean countries. Approximately 50-60\% of the processed fruit is transformed into citrus waste (peel, seeds and membrane residues), which must be processed in order to avoid the disposal of this residue in the soil resulting in further environmental problems (MARTíN et al., 2010). Thus orange peel can be used as an alternative and viable pectinase inducer.

\subsection{Effect of cultivation temperature and time-course on PG production}

N. glabra was cultivated at several temperatures for the analysis of the optimal cultivation temperature. The highest $P G$ activity occurred in the range from 30 to $35^{\circ} \mathrm{C}$ (Figure $3 \mathrm{~A}$ ) and $35^{\circ} \mathrm{C}$ was selected as the optimal temperature.
Using SbmF for the cultivation of N. glabra in Vogel's culture medium supplemented with $1 \%(\mathrm{w} / \mathrm{v})$ of orange peel (Citrus sinensis var. Bahia), higher extracellular PG activity (3.2 U/mL) was obtained after 72 hours of fermentation under static conditions at $35^{\circ} \mathrm{C}$. The PG activity remained approximately constant after $168 \mathrm{~h}$ of fermentation (Figure 3B). The significant secretion of extracellular PG facilitates its recovery from the fermentation medium, being more beneficial for the industry. The cultivation time may be dependent on the amount of nitrogen and carbon source available in the medium, since short periods of incubation may not result in the maximum production of the metabolite of interest. On the other hand, cultures incubated for long periods may lead to depletion of nutrients, cell death of the fungus and degradation of the enzymes (PELCZAR et al., 1996). Maciel et al. (2013) observed that the highest PG production by $A$. nigri occurred between 48 and $96 \mathrm{~h}$ and Patil et al. (2012) observed that $72 \mathrm{~h}$ was the optimal cultivation time for exo-PG production by Paecilomyces variotii.

\subsection{Effect of the carbon source concentration on PG production}

In the study of the effect of the carbon source concentration on the submerged fermentation of N. glabra under static conditions at $35^{\circ} \mathrm{C}$, higher $P G$ activity $(4 \mathrm{U} / \mathrm{mL})$ was obtained in Vogel's culture medium supplemented

Table 3. Influence of the mixture of two varieties of lemon peel on PG production.

\begin{tabular}{cccc} 
Mixture & Tahiti Lemon Peel (\%) & Sicilian Lemon Peel (\%) & Enzymatic Activity (U/mL) \\
\hline 1 & 1 & - & $3.78 \pm 0.25$ \\
3 & - & 1 & $3.28 \pm 0.43$ \\
4 & 0.5 & 0.5 & $2.69 \pm 0.26$ \\
5 & 0.75 & 0.25 & $2.58 \pm 0.30$ \\
\hline
\end{tabular}

The microorganism was cultivated in Vogel's medium and incubated under static conditions at $30^{\circ} \mathrm{C}$ for $96 \mathrm{~h}$.
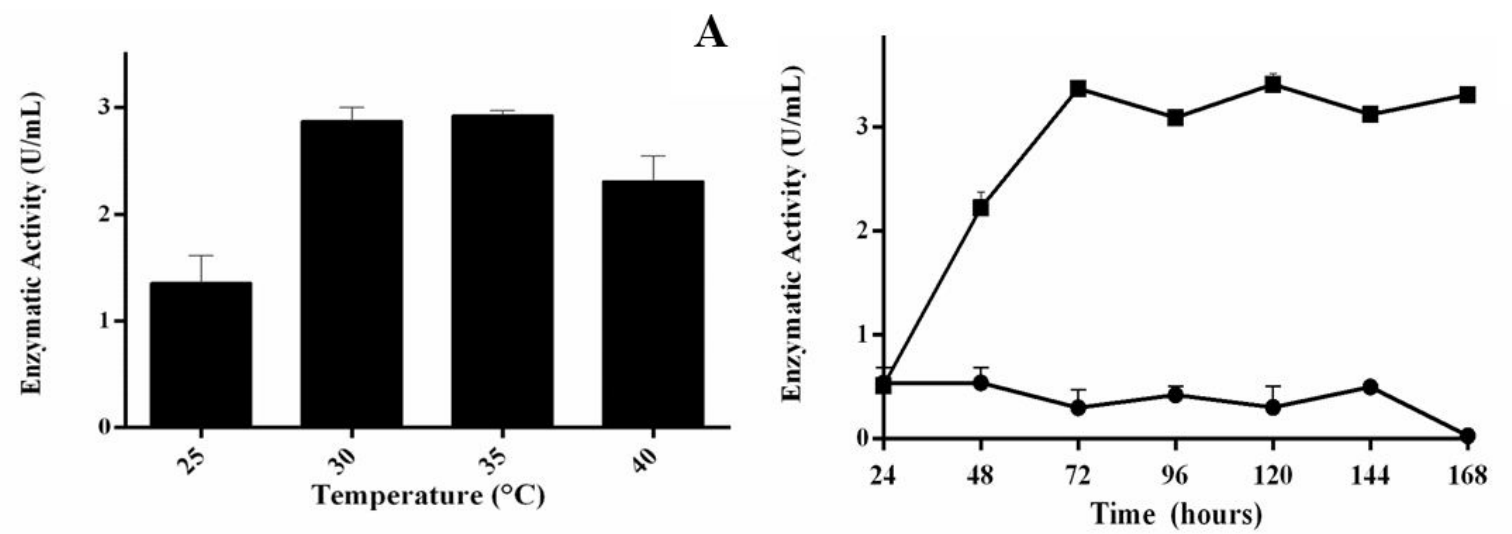

Figure 3. The effect of cultivation temperature (A) and time (B) on PG activity. Symbols: ( $\mathbf{a})$ extracellular and ( $\square$ ) intracellular PG activities. The microorganism was cultivated in Vogel's medium (SbmF) using orange peel (var. Bahia) as the carbon source and incubating under static conditions. 
Neosartorya glabra polygalacturonase produced from fruit peels as inducers has the potential for application in passion fruit and apple juices

Pinheiro, V. E. et al.

with $1.5 \%(\mathrm{w} / \mathrm{v})$ orange peel (Citrus sinensis var. Bahia) after $72 \mathrm{~h}$ (Figure 4). Camargo et al. (2005) observed the best production of the enzyme by Aspergillus sp. using $2 \%(w / v)$ orange bagasse in the cultivation medium.

The carbon source concentration is an important parameter to be determined in the optimization of fungal cultivations, because it is a precursor of the carbon chains for the synthesis of all the cell components. Low concentrations may be insufficient for inducing good enzyme levels and very high concentrations may act as inhibitors, since the excess (mainly complex substrates) can contain other sugars (monosaccharides), which have a higher affinity for the membrane transporters and are more easily captured by the fungus than is pectin, thereby decreasing the secretion of pectinase (KUBICEK, 2013). The inhibitory effect was observed with concentrations above $3 \%(w / v)$ of orange peel and could be correlated

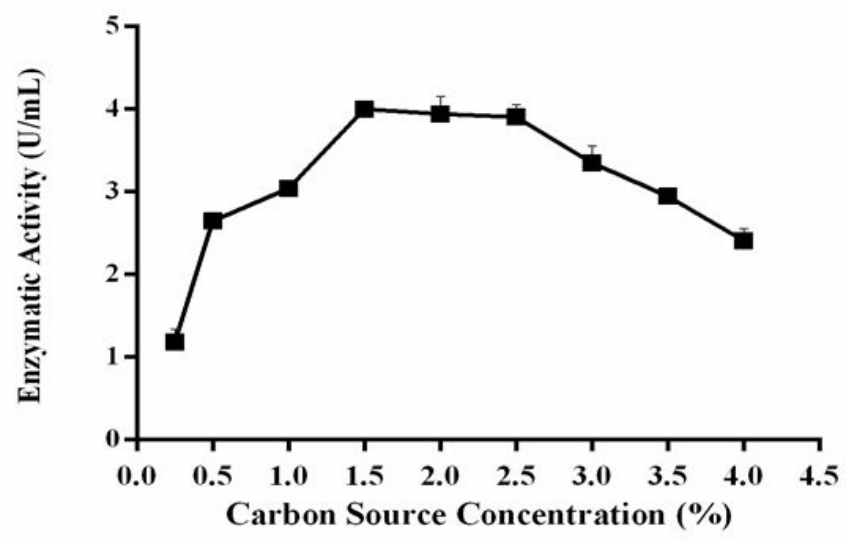

Figure 4. The effect of the carbon source concentration on PG production. The microorganism was cultivated in Vogel's medium (SbmF) using orange peel (var. Bahia) as the carbon source and incubated under static conditions at $35^{\circ} \mathrm{C}$ for $72 \mathrm{~h}$. with an excess of substrate, such as fruit processing residues and other compounds that lead to the death of the fungus, such as pesticides, very common in fruit peels (SIDDIQUI et al., 2012).

\subsection{Effect of temperature on PG activity}

The crude PG from Neosartorya glabra presented optimal activity at $50-60^{\circ} \mathrm{C}$ (Figure $5 \mathrm{~A}$ ) suggesting good applicability in processes involving high temperatures. Siddiqui et al. (2012) reported the optimal temperature as $55^{\circ} \mathrm{C}$ for the $\mathrm{PG}$ from Rhizomucor pusillus. Kashyap et al. (2001) observed maximum PG activity from $A$. niger at $50^{\circ} \mathrm{C}$ and Maller et al. (2011) reported the optimal temperature as $55^{\circ} \mathrm{C}$ for the $P G$ activity from $A$. niveus.

The PG from N. glabra retained more than $90 \%$ of its initial activity after $180 \mathrm{~min}$ at $40^{\circ} \mathrm{C}$. At $50^{\circ} \mathrm{C}$, the enzyme presented $a t_{50}$ of $150 \mathrm{~min}$ and at $60^{\circ} \mathrm{C}$ it was not stable (Figure 5B).

\subsection{Effect of pH on PG activity}

The crude PG from N. glabra presented optimal activity at pH 5.5 (Figure 6A). This result implies in applications in acidic processes, such as in the citrus juice industry. The PG from N. glabra showed stability at acid $\mathrm{pH}$ values when incubated in $100 \mathrm{mM}$ Mcllvaine buffer for 120 minutes at $25^{\circ} \mathrm{C}$. The incubation in buffer at $\mathrm{pH} 3.0$ resulted in an increase in residual activity of more than 20\% (Figure 6B) when compared to the control (non incubated enzyme). It has been reported that most pectic enzymes show stability under acidic $\mathrm{pH}$ conditions (GUMMADI; KUMAR, 2006). An acid solution presents a lot of free $\mathrm{H}^{+}$, which facilitates protonation of the $\mathrm{COOH}^{-}$ (glutamic acid and aspartic acid) and $\mathrm{NH}^{2-}$ (lysine, histidine and arginine) groups of the enzymes, directly influencing bonding to the substrate (SILVA; SILVA, 2010).
$\mathbf{A}$

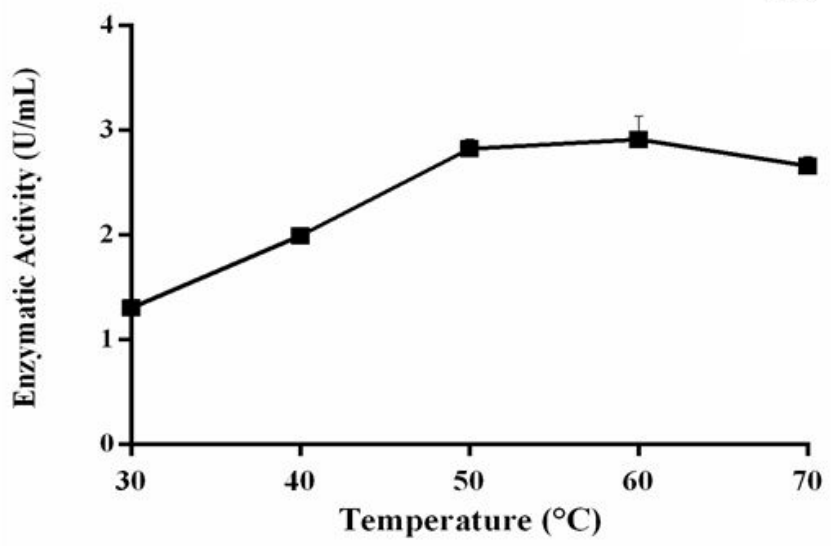

B

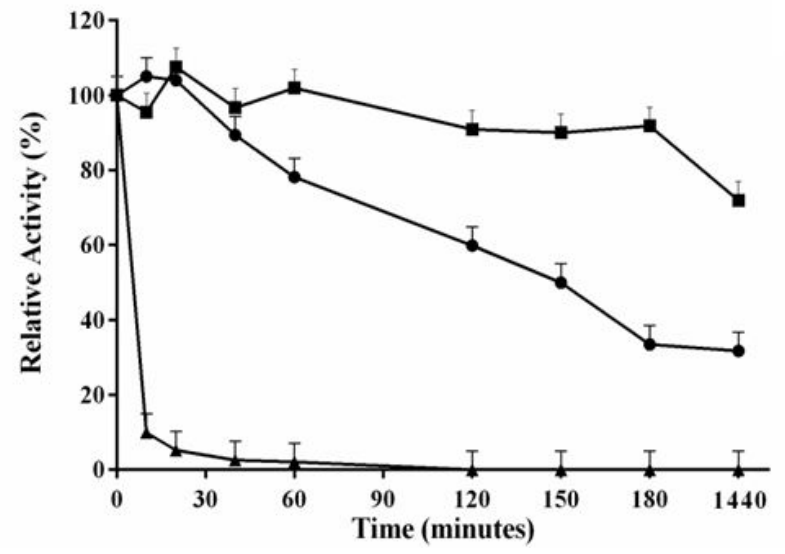

Figure 5. The effect of temperature on PG activity (A), thermostability of $P G$ at $\mathrm{pH} 5.5(\mathrm{~B})$. Symbols: thermal stability carried out at $40^{\circ} \mathrm{C}(\boldsymbol{\bullet}), 50^{\circ} \mathrm{C}(\bullet)$ and $60^{\circ} \mathrm{C}(\boldsymbol{\Delta})$. 
Neosartorya glabra polygalacturonase produced from fruit peels as inducers has the potential for application in passion fruit and apple juices

Pinheiro, V. E. et al.

\subsection{The application of the enzymatic extract in fruit juice processing}

The effect of the crude PG produced by N. glabra in reducing the viscosity of passion fruit and apple pulps was analysed. The treatment of passion fruit pulp with crude PG from N. glabra decreased the viscosity by $80 \%$, whereas treated apple pulps showed a $50 \%$ reduction in viscosity in relation to the untreated sample. In the juice industry, the pectin polymer present in the fruit pulp can interact with water molecules in an acidic medium and form a gel, increasing the viscosity. On account of this, it is common practice to apply pectinases to lower the viscosity and the water-binding capacity of the pectin, for easier juice extraction (NAKKEERAN et al., 2011; REHMAN et al., 2013). These results are in agreement with Domingues et al. (2014), who analysed the reduction in viscosity of passion fruit juice samples using the enzymatic complex Pectinex 3XL from Novozymes, and verified that the enzymatic treatment was efficient in reducing the viscosity. Laorko et al. (2010) also used the enzymatic treatment of apple juices before micro- and ultrafiltration tests. Patil et al. (2012) tested an exo-PG produced by Paecilomyces variotii in the treatment of fruit juices, and observed viscosity decreases in orange, apple, grape, banana and guava juices. Tu et al. (2013) reported a $17.6 \%$ viscosity reduction in papaya juice with the application of an endo-PG.

The turbidity of the treated and untreated pulps was analysed via light absorbance at different wavelengths in a spectrophotometer. The juices treated with crude PG showed different values for absorbance at the different wavelengths as compared to the untreated juice (control). Treated passion fruit juice showed a higher difference in absorbance between 430-500 nm (Figure 7A) and at these wavelengths the light absorbance of the treated samples was shown to decrease by $75 \%$. For apple samples, the
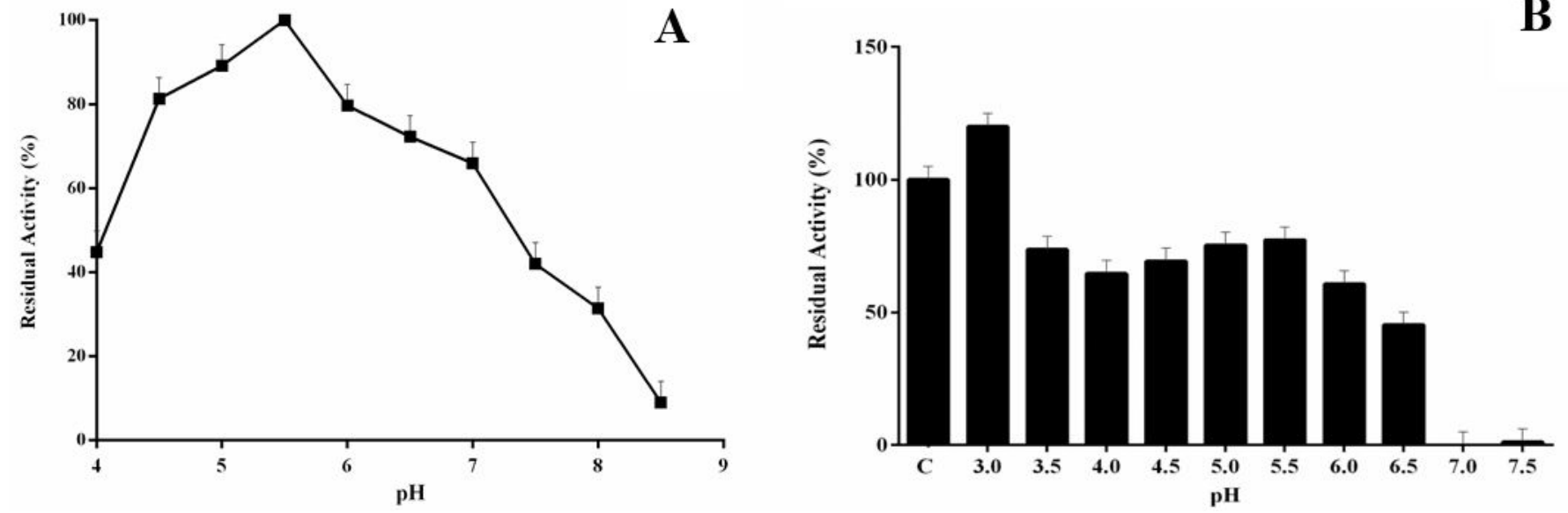

Figure 6. The effect of $\mathrm{pH}$ on $\mathrm{PG}$ activity (A), $\mathrm{pH}$ stability of $\mathrm{PG}$ at $25^{\circ} \mathrm{C}$ for 120 minutes $(\mathrm{B})$. $\mathrm{C}=$ control.
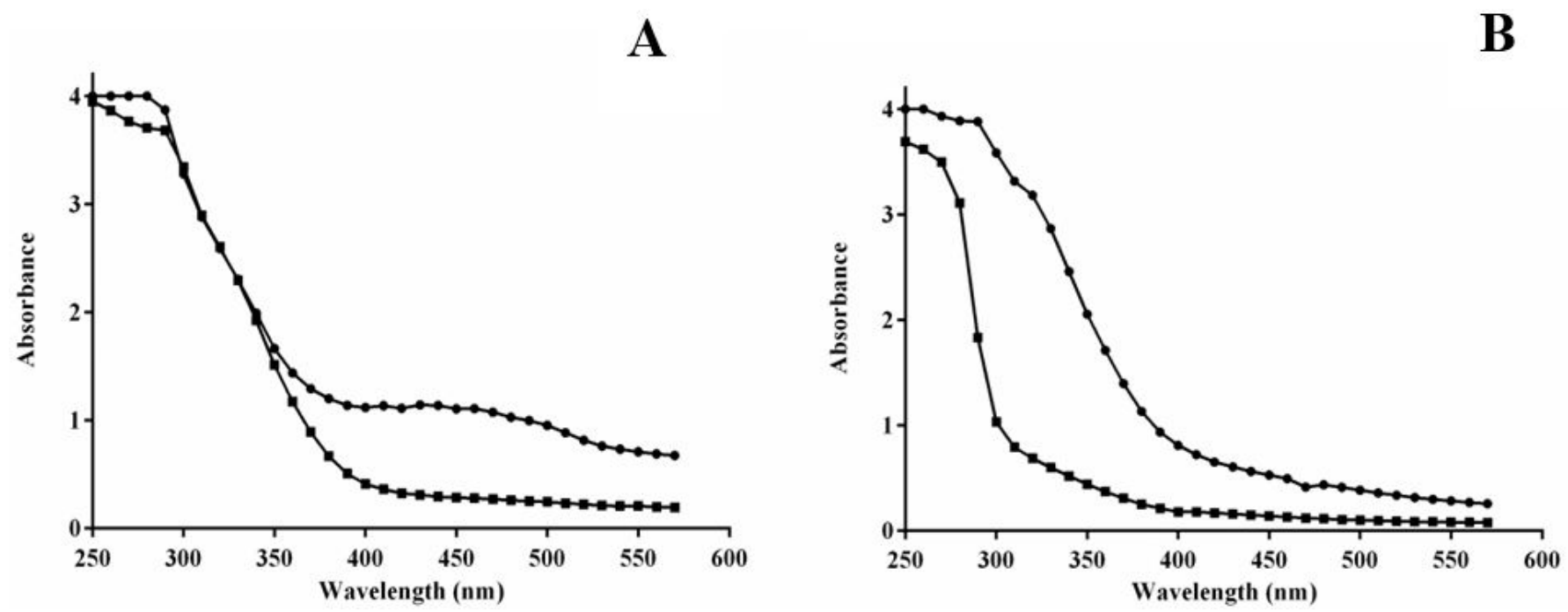

Figure 7. Estimation of the turbidity of the juices. The values for absorbance of treated and untreated passion fruit juice samples $(A)$, and apple juice samples (B). Symbols: untreated samples - control (•), treated samples ( $\mathbf{\bullet})$. 
Neosartorya glabra polygalacturonase produced from fruit peels as inducers has the potential for application in passion fruit and apple juices

Pinheiro, V. E. et al.

highest difference in absorbance was observed between 320-360 nm (Figure 7B) and at these wavelengths the light absorbance of the treated samples was shown to decrease by $78 \%$. These data suggest the range of wavelengths that could be used to estimate the hydrolysis caused by the enzyme action and the decrease in light absorbance after enzyme treatment, which is an indicator of the decrease in turbidity.

\section{Conclusion}

The use of residues from fruit juice processing as a carbon source, especially orange peel (var. Bahia), was favourable for PG production by N. glabra. This result was very interesting since the use of low-cost substrates is required in industrial processes. Optimal PG production conditions were obtained with $1.5 \%$ dried and ground orange peel (Bahia) as the carbon source when using SbmF, cultivating the microorganism in Vogel's minimal medium and incubating at $35^{\circ} \mathrm{C}$ for $72 \mathrm{~h}$. The $P G$ of the crude extract presented optimal activity at $50-60^{\circ} \mathrm{C}$ and $\mathrm{pH} 5.5$ The enzyme was highly stable at $40^{\circ} \mathrm{C}$ for 180 minutes and retained $50 \%$ of the initial activity after 150 minutes at $50^{\circ} \mathrm{C}$. The PG was stable in the acidic range after 120 minutes of treatment at $25^{\circ} \mathrm{C}$. The enzyme extract obtained under the optimized condition was used in the extraction of fruit juices and in the application tests, where it showed a reduction in viscosity of $80 \%$ and a decrease in light absorbance of $75 \%$ with the passion fruit pulps, and a reduction in viscosity of $50 \%$ and decrease in light absorbance of $78 \%$ with the apple pulps. This work contributes to the improvement of knowledge on the influence of physical-chemical factors on the production of polygalacturonase by Neosartorya glabra and its success in the application to passion fruit and apple pulps.

\section{Acknowledgements}

The authors are grateful to Mariana Cereia, Ricardo Alarcon and Maurício de Oliveira for their technical assistance. This work was supported by the Fundação de Amparo à Pesquisa do Estado de São Paulo (FAPESP, process 2010/52322-3) and the Conselho de Desenvolvimento Científico e Tecnológico (CNPq, process 563260/2010-6). J. A. J. and M. L. T. M. P. are Research Fellows of CNPq. V. E. P. was the recipient of a FAPESP fellowship (Process 2013/01077-7).

\section{References}

AL-SAADI, N. H. M.; AHMAD, N. S.; SA'EED, S. E. Determination of some chemical compounds and the effect of oil extract from orange peel on some pathogens. Journal of Kerbala University, Karbala, v. 7, n. 2, p. 33-39, 2009.

BATOOL, S.; ASAD, M. J.; NAQVI, S. S.; MAHMOOD, R. T.; GUFFAR, A.; GULFRAZ, M.; HADRI, S. H. Production and partial purification of pectin lyase by Aspergillus niger grown on orange peels. African Journal of Microbiological Research, Lagos, v. 7, n. 13, p. 1144-1149, 2013

CAMARGO, L. A.; DENTILLO, D. B.; CARDELLO, L.; GATTÁS, E. A. L. Use of orange peel in pectinases production Aspergillus sp. Alimentos e Nutrição, Araraquara, v. 16, p. 153-156, 2005.

CANTERI, M. H. G. Caracterização comparativa entre pectinas extraídas do pericarpo de maracujá-amarelo (Passiflora edulis f. flavicarpa). 2011. $162 \mathrm{f}$. Tese (Doutorado em Tecnologia de Alimentos)-Universidade Federal do Paraná, Curitiba, 2011.

CANTERI, M. H. G.; MORENO, L.; WOSIACKI, G.; SCHEER, A. P. Pectin: from raw material to the final product. Polímeros, São Carlos, v. 22, n. 2, p. 149-157, 2012. http://dx. doi.org/10.1590/ S0104-14282012005000024.

CARVALHO G. G. P.; FERNANDES F. E. P.; PIRES A. J. V. Métodos de determinação dos teores de amido e pectina em alimentos para animais. Revista Electrónica de Veterinária - REDVET, Andalucía, v. 7, n. 1, p. 1-12, 2006.

DOMINGUES, R. C. C.; RAMOS, A. A.; CARDOSO, V. L.; REIS, M. H. M. Microfiltration of passion fruit juice using hollow fibre membranes and evaluation of fouling mechanisms. Journal of Food Engineering, London, v. 121, p. 73-79, 2014. http://dx.doi. org/10.1016/j.jfoodeng.2013.07.037.

FÉRNANDEZ, D. E. R. Desenvolvimento de um bioprocesso por fermentação em estado sólido para produzir e recuperar enzimas de interesse comercial. 2009. $126 \mathrm{f}$. Tese (Doutorado em Processos Biotecnológicos)-Universidade Federal do Paraná, Curitiba, 2009.

FOOD AND AGRICULTURE ORGANIZATION OF THE UNITED NATIONS - FAOSTAT. Crops. Rome, 2016. Available at: <http:// faostat3.fao.org/browse/Q/QC/E>. Accessed on: 20 oct. 2016.

GUMMADI, S. N.; KUMAR, D. S. Enhanced production of pectin lyase and pectate lyase by Debaryomyces nepalensis in submerged fermentation by statistical methods. American Journal of Food Technology, New York, v. 1, n. 1, p. 19-33, 2006. http://dx.doi.org/10.3923/ajt.2006.19.33.

INSTITUTO FLORESTAL - IF. Bebedouro. São Paulo, 2016. Available at: <http://iflorestal.sp.gov.br/areas-protegidas/florestasestaduais/bebedouro/>. Accessed on: 31 oct. 2016.

IRSHAD, M.; ANWAR, Z.; MAHMOOD, Z.; AQIL, T.; MAHMOOD, S.; NAWAZ, H. Bio-processing of agro-industrial waste orange peel for induced production of pectinase by Trichoderma viridi; its purification and characterization. Turkish Journal of Biochemistry, Ankara, v. 39, n. 1, p. 9-18, 2014. http://dx. doi. org/10.5505/tjb.2014.55707.

KANT, S.; VOHRA, A.; GUPTA, R. Purification and physicochemical properties of polygalacturonase from Aspergillus niger MTCC 3323. Protein Expression and Purification, San Diego, v. 87, n. 1, p. 11-16, 2013. PMid:23069766. http://dx.doi.org/10.1016/j. pep.2012.09.014. 
Neosartorya glabra polygalacturonase produced from fruit peels as inducers has the potential for application in passion fruit and apple juices

Pinheiro, V. E. et al.

KASHYAP, D. R.; VOHRA, P. K.; CHOPRA, S.; TEWARI, R. Applications of pectinases in the commercial sector: a review. Bioresource Technology, Barking, v. 77, n. 3, p. 215-227, 2001. PMid:11272008. http://dx.doi.org/10.1016/S0960-8524(00)00118-8.

KAUR, G.; KUMAR, S.; SATYANARAYANA, T. Production characterization and application of a thermostable polygalacturonase of a thermophilic mould Sporotrichum thermophils Apinis. Bioresource Technology, Barking, v. 94, n. 3, p. 239-243, 2004. PMid:15182829. http://dx.doi.org/10.1016/j.biortech.2003.05.003.

KUBICEK, C. P. Fungi and lignocellulosic biomass. Ames: Willey-Blackwell, 2013

LAORKO, A.; ZHENYU, L.; TONGCHITPAKDEE, S.; CHANTACHUM, S.; YOURAVONG, W. Effect of membrane property and operating conditions on phytochemical properties and permeate flux during clarification of pineapple juice. Journal of Food Engineering, London, v. 100, n. 3, p. 514-521, 2010. http://dx.doi.org/10.1016/j. jfoodeng.2010.04.039.

MACIEL, M. H. C.; OTTONI, C.; SANTOS, C.; LIMA, N.; MOREIRA, K. A.; SOUZA-MOTTA, C. M. Production of polygalacturonases by Aspergillus section Nigri strains in a fixed bed reactor. Molecules, Switzerland, v. 18, n. 2, p. 1660-1671, 2013. PMid:23358324. http://dx.doi.org/10.3390/molecules18021660.

MAKKY, E. A.; YUSOFF, M. M. Bioeconomy: pectinases purification and application of fermented waste from Thermomyces lanuginosus. Journal of Medical and Bioengineering, Singapore, v. 4, n. 1, p. 76-80, 2015. http://dx.doi.org/10.12720/jomb.4.1.76-80.

MALLER, A.; DAMÁSIO, A. R. L.; SILVA, T. M.; JORGE, J. A.; TERENZI, H. F.; POLIZELI, M. L. T. M. Biotechnological potential of agro-industrial wastes as a carbon source to thermostable polygalacturonase production in Aspergillus niveus. Enzyme Research, London, v. 2011, p. 1-6, 2011. PMid:21837272. http:// dx.doi.org/10.4061/2011/289206.

MARTíN, M. A.; SILES, J. A.; CHICA, A. F.; MARTíN, A. Biomethanization of orange peel waste. Bioresource Technology, Barking, v. 101, n. 23, p. 8993-8999, 2010. PMid:20655741. http://dx.doi.org/10.1016/j.biortech.2010.06.133.

MELETTI, L. M. M. Advances of the passion fruit crop in Brazil. Revista Brasileira de Fruticultura, Jaboticabal, v. 33, n. 1, p. 83-91, 2011. http://dx.doi.org/10.1590/S0100-29452011000500012.

MILLER, G. L. Use of dinitrosalicylic acid reagent for determination of reducing sugar. Analytical Chemistry, Washington, v. 31, n. 3, p. 426-429, 1959. http://dx.doi.org/10.1021/ac60147a030.

MRUDULA, S.; ANITHARAJ, R. Pectinase production in solid state fermentation by Aspergillus niger using orange peel as substrate. Global Journal of Biotechnology \& Biochemistry, London, v. 6, p. 64-71, 2011.

NAKKEERAN, E.; UMESH KUMAR, S.; SUBRAMANIAN, R. Aspergillus carbonarius polygalacturonases purified by integrated membrane process and affinity precipitation for apple juice production. Bioresource Technology, Barking, v. 102, n. 3, p.
3293-3297, 2011. PMid:21051226. http://dx.doi.org/10.1016/j. biortech.2010.10.048.

NEVADITA, S.; NADHU, R.; MUKESH, S. Microbial pectinase: source characterization and applications. Reviews in Environmental Science and Bio/Technology, The Netherlands, v. 12, n. 1, p. 45-60, 2013. http://dx.doi.org/10.1007/s11157-012-9276-9.

OLIVEIRA, D. A.; ANGONESEA, M.; GOMES, C.; FERREIRA, S. R. S. Valorization of passion fruit (Passiflora edulis sp.) by-products: sustainable recovery and biological activities. The Journal of Supercritical Fluids, Cincinnati, v. 111, p. 55-62, 2016. http:// dx.doi.org/10.1016/j.supflu.2016.01.010.

ONGARATTO, R. S.; VIOTTO, L. A. Enzyme optimization to reduce the viscosity of pitanga (Eugenia uniflora L.) juice. Brazilian Journal of Food Technology, Campinas, v. 19, p. e2015041, 2016.

PATIL, N. P.; PATIL, K. P.; CHAUDHARZ, B. L.; CHINCHOLKAR, S. B. Production purification of exo-polygalacturonase from soil isolate Paecilomyces variotii NFCCI 1769 and its application. Indian Journal of Microbiology, Calcutta, v. 52, n. 2, p. 240-246, 2012. PMid:23729888. http://dx.doi.org/10.1007/s12088-011-0162-x.

PELCZAR, M. J. J.; REID, R.; CHAN, E. C. S. Microbiology. São Paulo: Makron Books, 1996.

REHMAN, H. U.; AMAN, A.; SILIPO, A.; QADER, S. A. U.; MOLINARO, A.; ANSARI, A. Degradation of complex carbohydrate: Immobilization of pectinase from Bacillus licheniformis KIBGE-IB 21 using calcium alginate as a support. Food Chemistry, London, v. 139, n. 1-4, p. 1081-1086, 2013. PMid:23561212. http://dx.doi. org/10.1016/j.foodchem.2013.01.069.

RIDLEY, B. L.; O'NEIL, M. A.; MOHNEN, D. Pectins: structure biosynthesis and oligogalacturonide-related signalling. Phytochemistry, Oxford, v. 57, n. 6, p. 929-967, 2001. PMid:11423142. http://dx.doi.org/10.1016/S0031-9422(01)00113-3.

ROBOZ, E.; BARRAT, R. W.; TATUM, E. L. Breakdown of pectic substances by a new enzyme from Neurospora. The Journal of Biological Chemistry, Baltimore, v. 195, n. 2, p. 459-471, 1952. PMid: 14946155.

SCHWAN-ESTRADA, K. R. F.; STANGARLIN, J. R.; CRUZ, M. E. S. Uso de extratos vegetais no controle de fungos fitopatogênicos. Floresta, Curitiba, v. 30, n. 12, p. 129-137, 2000. http://dx.doi. org/10.5380/rf.v30i12.2361.

SERVIÇO BRASILEIRO DE APOIO ÀS MICRO E PEQUENAS EMPRESAS - SEBRAE. O cultivo e o mercado da maçã. Brasília, 2016. Available at: <https://www.sebrae.com.br/sites/ PortalSebrae/artigos/o-cultivo-e-o-mercado-da-maca>. Accessed on: 31 oct. 2016.

SIDDIQUI, M. A.; PANDE, V.; ARIF, M. Production purification and characterization of polygalacturonase from Rhizomucor pusillus isolated from decomposting orange peels. Enzyme Research, London, v. 2012, p. 1-8, 2012. PMid:23125919. http://dx.doi. org/10.1155/2012/138634. 
Neosartorya glabra polygalacturonase produced from fruit peels as inducers has the potential for application in passion fruit and apple juices

Pinheiro, V. E. et al.

SILVA, S. N.; SILVA, C. R. R. Técnico em alimentos. Brasília: E-tec Rede Brasil, 2010. Available at: <http://200.17.98.44/ pronatec/wp-intent/uploads/2013/06/Tecnologia_de_Bebidas. pdf>. Accessed on: 10 Jan. 2015.

SIN, H. N.; YUSOF, S.; HAMID, N. S. A.; RAHMAN, R. A. Optimization of enzymatic clarification of sapodilla juice using response surface methodology. Journal of Food Engineering, London, v. 73, n. 4, p. 313-319, 2006. http://dx.doi.org/10.1016/j. jfoodeng.2005.01.031.

SUBRAMANIYAM, R.; VIMALA, R. Solid state and submerged fermentation for the production of bioactive substance: a comparative study. International Journal of Science and Nature, Lucknow, v. 3, n. 3, p. 480-486, 2012.

TAI, E.; HSIEH, P.; SHEU, S. Purification and characterization of polygalacturonase from screened Aspergillus tubingensis for coffee processing. Food Science and Technology Research, Tsukuba, v. 19, n. 5, p. 813-818, 2013. http://dx.doi.org/10.3136/ fstr.19.813.
TU, T.; MENG, K.; BAI, Y.; SHI, P.; LUO, H.; WANG, Y.; YANG, P.; ZHANG, Y.; ZHANG, W.; YAO, B. High-yield production of a low-temperature-active polygalacturonase for papaya juice clarification. Food Chemistry, London, v. 141, n. 3, p. 2974-2981, 2013. PMid:23871048. http://dx.doi.org/10.1016/j. foodchem.2013.05.132.

UENOJO, M.; PASTORE, G. M. Pectinases: industrial applications and perspectivase. Quimica Nova, São Paulo, v. 30, n. 2, p. 388-394, 2007. http://dx.doi.org/10.1590/S0100-40422007000200028.

VOGEL, H. F. Distribution of lisine pathways among fungi: evolutionary implications. The American Naturalist, Chicago, v. 98, n. 903, p. 435-446, 1964. http://dx.doi.org/10.1086/282338.

ZENI, J.; CENCE, K.; GRANDO, C. E.; TIGGERMANN, L.; COLET, R.; LERIN, L. A.; CANSIAN, R. L.; TONIAZZO, G.; OLIVEIRA, D.; VALDUGA, E. Screening of pectinase-producing microorganisms with polygalacturonase activity. Applied Biochemistry and Biotechnology, Clifton, v. 163, n. 3, p. 383-392, 2011. PMid:20669053. http://dx.doi.org/10.1007/s12010-010-9046-5. 